\title{
A magyarországi vasúti és távolsági autóbuszos személyszállítás párhuzamosságának kérdései az utazási paraméterek szempontjából
}

\author{
Magyarország közlekedésében visszatérő problémát jelent a tá- \\ volsági autóbuszos és vasúti személyszállítás párhuzamossága, \\ amelynek vizsgálata a hatékonyság javítása céljából rendkívül \\ fontos. A megoldás érdekében szükséges a jelenlegi párhuzamos \\ közösségi közlekedés lehetőségeinek optimalizálása.
}

DOI 10.24228/KTSZ.2017.3.5

\section{Dr. Mándoki Péter - Lakatos András}

egyetemi docens doktorandusz

e-mail: mandoki.peter@mail.bme.hu, lakatos.andras@mail.bme.hu

\section{BEVEZETÉS}

Magyarország közösségi közlekedése meghatározó szerepet tölt be az emberek életében és nagyban befolyásolja a nemzetgazdaság alakulását is, ezért fejlesztése elengedhetetlen. Ugyan az infrastrukturális innováció - a kormányzati és Európai Uniós forrásoknak köszönhetően - folyamatos (autópályák építése, vasúti pályák felújítása), azonban a makroszkopikus forgalomszervezési feladatok a háttérbe kerülnek. A hálózat teljes egészére vonatkozó szemléletmód is fontos részét képezi a fejlesztésnek, amelynek alkalmazásával az infrastrukturális beruházás tökéletesíthető, valamint az üzemeltetés során anyagi és emberi erőforrás takarítható meg.

A szakmai kutatás egyik alappillérét képezi a közlekedési hálózat egészére kiterjedő vizsgálatok elvégzése, amelynek első lépése a budapesti villamosközlekedés versenyképességének optimalizációval történő növelése volt [21]. Ennek során a jelenlegi megállóhelyi utasforgalom elemzése történt a jármüvön továbbutazókhoz mérten, azaz az adott megállóhelyet napi szinten igénybe vevő utasok száma - a továbbutazók utazási idejének kárára - indokolja-e a jármü megállítását?
Jelen vizsgálat tárgya, hogy a hazai vasúti és távolsági autóbuszos személyszállítás terén a párhuzamosságok egy makroszkopikus - az egész hálózatot magába foglaló - megközelítéssel optimalizálhatók-e?

\section{VIZSGÁLATI MÓDSZER, ELEMZÉS}

Az optimalizálás érdekében a különböző üzemi és felhasználói szempontok alapján összehasonlítottuk az olyan párhuzamos viszonylatokat, amelyek Budapest és néhány vidéki megyeszékhely (Zalaegerszeg, Székesfehérvár, Veszprém, Kecskemét, Kaposvár, Eger), de minimum megyei jogú város (Dunaújváros) vagy 20 ezer főnél nagyobb lélekszámú városok (Hatvan, Keszthely) között üzemelnek. A városközponttól városközpontig tartó utazási láncok figyelembevételével, a vasút-, illetve autóbusz-állomás megközelítésének, illetve elhagyásának a meghatározása az 1. ábra szerint történt. Az 1. ábrából kivehető, hogy az állomások földrajzi elhelyezkedéséből adódóan fennáll annak a lehetősége is, hogy vagy az autóbusznál, vagy a vasútnál, vagy mindkettőnél sincs szükség városon belüli rá-, illetve elhordásra. 


\section{Közösségi iözlekedés}

1. ábra: Utazási lánc Budapest és a vizsgált vidéki városok között
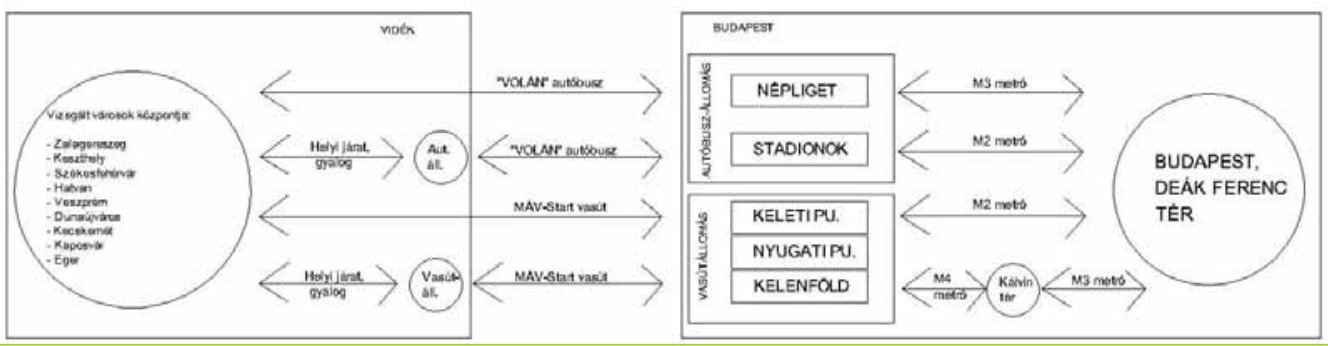

Az ábrában szereplő városok közötti relációkban a távolsági jármüvön töltött utazási idő- és megtett távolsági adatok meghatározása a [8], [12] alapján történt.

Az eljutási idő az utazási idő, valamint a rá- és elhordási idő, az eljutási távolság a ráés elhordási távolság és az utazási távolság összegeként értelmezhető. Ezen értékeket az 1. táblázat tartalmazza. Amennyiben az adott viszonylaton eltérő menetidővel közlekednek a járatok, úgy azok számtani átlagát vettük figyelembe.

A számítás alapját Budapest Deák Ferenc tér és budapesti autóbusz-állomás vagy vasútállomás közötti szakaszon a különböző alternatív útvonalak közül a legkisebb időigénynyel rendelkező képezi. Részletesen ez a
- Nyugati pályaudvar megközelítése esetén az M3 metró (3 perc, 1,5 kilométer),

- Keleti pályaudvar esetén az M2 metró (5 perc, 2,5 kilométer),

- Kelenföld esetén az M3 metró Kálvin térig, majd onnan az M4 metró (átszállással 17 perc, 5,8 kilométer),

- Stadionok esetén az M2 metró (7 perc, 4,3 kilométer),

- Népliget esetén pedig az M3 metró (7 perc, 4,3 kilométer) igénybevételét jelenti [1].

A vasút-, illetve az autóbusz-állomáson minden esetben 10 perc átszállási idővel számoltunk, amelyről feltételeztük, hogy az átlagosan elegendő a menetjegy megvásárlására és a helyszínen az indulással kapcsolatos információk beszerzésére, a jármű megközelítésére stb.

\section{1. táblázat: Autóbusz és vonat eljutási idő- és távolsági paraméterei a vizsgált viszonylatokon}

\begin{tabular}{|c|c|c|c|c|c|c|c|c|c|c|c|c|}
\hline & \multicolumn{5}{|c|}{ Autóbusz } & \multicolumn{4}{|c|}{ Vonat } & \multirow{3}{*}{\begin{tabular}{|c|} 
Különbség \\
$\begin{array}{c}\text { Rá- és } \\
\text { elhordási } \\
\text { idö [perc] }\end{array}$ \\
\end{tabular}} & \multirow{2}{*}{\multicolumn{2}{|c|}{$\begin{array}{c}\text { Autóbusz-vonat } \\
\text { küllönbség }\end{array}$}} \\
\hline & \multicolumn{2}{|c|}{ Eljutási } & \multicolumn{2}{|c|}{ Utazási } & \multirow{2}{*}{\begin{tabular}{|c|} 
Különbség \\
Rá- és \\
elhordási \\
idő [perc]
\end{tabular}} & \multicolumn{2}{|c|}{ Eljutási } & \multicolumn{2}{|c|}{ Utazási } & & & \\
\hline & Távolság [km] & Idō [perc] & $\begin{array}{c}\text { Távolság } \\
\text { [km] }\end{array}$ & Idổ [perc] & & Távolság [km] & $\begin{array}{c}\text { Eljutási idó } \\
\text { [perc] }\end{array}$ & \begin{tabular}{|c|} 
Távolság \\
[km]
\end{tabular} & $\begin{array}{c}\text { Idő } \\
\text { [perc] }\end{array}$ & & \begin{tabular}{|c|} 
Távolság \\
[km]
\end{tabular} & $\begin{array}{c}\text { Eljutási } \\
\text { idő } \\
\text { [perc] }\end{array}$ \\
\hline Székesfehérvár & 72,9 & 95 & 68,4 & 75 & 20 & 70,3 & 85 & 63 & 51 & 34 & 2,6 & 10 \\
\hline Dunaújváros & 79,7 & 95 & 75,2 & 75 & 20 & 88,3 & 148 & 80 & 95 & 53 & $-8,6$ & -53 \\
\hline Eger & 132,6 & 127 & 128,3 & 110 & 17 & 144 & 151 & 140 & 116 & 35 & $-11,4$ & -24 \\
\hline Kecskemét & 84,6 & 90 & 80,1 & 70 & 20 & 107,5 & 90 & 106 & 77 & 13 & $-22,9$ & 0 \\
\hline Zalaegerszeg & 237 & 219,5 & 233 & 191 & 29 & 246,4 & 251 & 239 & 211 & 40 & $-9,4$ & -32 \\
\hline Keszthely & 193,9 & 165 & 189,4 & 145 & 20 & 195,8 & 193 & 190 & 166 & 27 & $-1,9$ & -28 \\
\hline Veszprém & 118,5 & 146 & 114 & 126 & 20 & 120,6 & 141 & 112 & 99 & 42 & $-2,1$ & 5 \\
\hline Kaposvár & 195,6 & 175 & 191,8 & 155 & 20 & 209,8 & 180 & 204 & 166 & 14 & $-14,2$ & -5 \\
\hline Hatvan & 60,7 & 7 & 56,4 & 60 & 17 & 69,5 & 66 & 67 & 51 & 15 & $-8,8$ & 11 \\
\hline Debrecen & 223 & 228 & 217,4 & 200 & 28 & 223,6 & 173 & 221 & 149 & 24 & $-1,05$ & 55 \\
\hline Nyíregyháza & 231 & 237 & 226,3 & 220 & 17 & 272 & 196 & 270 & 182 & 14 & $-41,4$ & 41 \\
\hline Pécs & 212,8 & 268 & 208,3 & 248 & 20 & 230,7 & 203 & 224 & 163 & 40 & $-17,85$ & 65 \\
\hline Szeged & 177,3 & 204 & 172,8 & 184 & 20 & 195,2 & 172 & 191 & 142 & 30 & $-17,9$ & 32 \\
\hline Szombathely & 234 & 285 & 229,4 & 265 & 20 & 237,2 & 200 & 230 & 145 & 55 & $-3,3$ & 85 \\
\hline Györ & 132,1 & 130 & 127,6 & 110 & 20 & 132,8 & 97 & 127 & 70 & 27 & $-0,7$ & 33 \\
\hline
\end{tabular}




\section{Közösségi közlekedés}

Az olyan vonalak, amelyeken jelenleg közvetlenül csak vasúti személyszállítás van (pl.: Budapest - Debrecen, Budapest - Györ, városközpont), autóbuszos nincs, ott csupán elméleti (empirikus úton a hivatalos menetrendekben nem korrigált) értékeket tüntettük fel. A Budapest - Debrecen viszonylatban a csak külön rendeletre közlekedő - a 2008-as vasutassztrájk idején felmért - 1060 Budapest - Debrecen menetrendi mező adatai a mérvadóak. Budapest - Győr viszonylatában pedig a 2013. évben megszüntetett 1260 Budapest - Győr menetrendi mezők adatait használtuk fel.

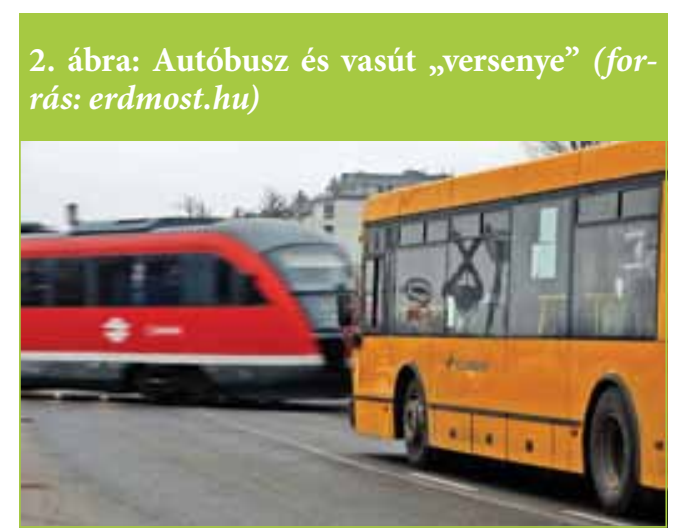

Az utazási időt nagyban befolyásolja vasút esetében a pályán megengedett maximális sebesség, autóbusz esetében pedig az, hogy a fóváros és az adott település között van-e autópályás kapcsolat. A vizsgált települések és a főváros között - a lakott területen kívüli szakaszon - részlegesen (pl. Zalaegerszeg, amelynek megközelítése Balatonszentgyörgytől a 76-os számú föúton) vagy teljes egészében (pl. Székesfehérvár) van autópályás kapcsolat. A vasúti pályán a legnagyobb tervezési sebesség minimum $100 \mathrm{~km} / \mathrm{h}$ [13]. A ráhordási idő az adott város helyi közösségi közlekedési kapcsolatainak térbeniségétől és időbeliségétől függ.

\section{ESZKÖZVÁLASZTÁS A FELHASZ- NÁLÓI OLDALRÓL}

A felhasználói oldalról az eszközválasztást meghatározza az eljutási idő mértéke, valamint az utazás költsége. Döntö többségben ezeket mérlegelve dönti el az utas, melyik rendelkezésre álló - közlekedési módot választja.

\subsection{Eljutási idő allapján}

Budapest és a vizsgált városok közötti, különböző közlekedési módokkal számított eljutási idő- és távolságértékek összehasonlítására a Ritz-féle módszerek családjába tartozó regressziós függvényeket alkalmaztuk. A regressziós függvények lineárisan független rendszert alkotnak, tehát egyik függvény sem fejezhető ki a többi lineáris kombinációjaként.

A szóba kerülő függvények lehetnek trigonometrikusak, exponenciálisak, illetve n-ed (páros és páratlan) fokszámú polinomok.

A trigonometrikus függvények alkalmazása elsősorban periodikus folyamatok leírására megfelelő, ezért az abból következő hibák - mivel a jelenség nem periodikus - miatti felhasználása a vizsgálat szempontjából nem célszerü. Az exponenciális függvény használata - az előzőhez hasonlóan - a várható nagy hibából kifolyólag nem szerencsés.

Páros fokszámú polinom a vizsgálat belső tartományán jól alkalmazható, de a jelenség vizsgálatára a szélső helyeken nem hasznosítható megfelelően. A páratlan fokszámú polinomok viszont teljesítik azt a feltételt, hogy a szélső helyeken is alkalmasak a jelenség jellemzésére.

A fentiek és a [18] alapján olyan első-, harmad-, ötödfokú polinomokat kerestünk, amelyek a legjobban illeszkednek az 1. táblázatban található értékpárokhoz.

A különböző, páratlan fokszámú regressziók az n-ed fokú polinom (1)

$$
f(x, \underline{a})=a_{1}+a_{2} x^{1}+a_{3} x^{2}+a_{4} x^{3}+\ldots+a_{n+1} x^{n}
$$

alakú egyenletéből vezethetőek vissza, ahol $\mathrm{az} \underline{\mathrm{a}}=\left[\mathrm{a}_{1}, \mathrm{a}_{2}, \mathrm{a}_{3}, \ldots, \mathrm{a}_{\mathrm{n}+1}\right]$ ismeretlenek meghatározása az 


\section{Közösségi iözlekedés}

$$
\begin{gathered}
1 \cdot a_{1}+M\left[x_{i}\right] a_{2}+\cdots+M\left[x_{i}^{n}\right] a_{n+1}=M\left[y_{i}\right] \\
M\left[x_{i}\right] a_{1}+M\left[x_{i}^{2}\right] a_{2}+\cdots+M\left[x_{i}^{n+1}\right] a_{n+1}=M\left[y_{i} x_{i}\right] \\
- \\
M\left[x_{i}^{n}\right] a_{1}+M\left[x_{i}^{n+1}\right] a_{2}+\cdots+M\left[x_{i}^{2 n}\right] a_{n+1}=M\left[y_{i} x_{i}^{n}\right]
\end{gathered}
$$

(2), (3), (4) egyenletekből álló egyenletrendszer alapján történik.

Lineáris (elsőfokú) regresszió során az adott értékpárokra legjobban egy egyenes (5) illeszthetö, amely az

$$
f(x, \underline{a})=a_{1}+a_{2} x
$$

alakban adható meg, amelyben az $\underline{a}=\left[\mathrm{a}_{1}, \mathrm{a}_{2}\right]$ ismeretlen az alábbi, kétismeretlenes egyenletrendszer (6), (7) megoldásával kapható meg

$$
\begin{aligned}
M\left[\left(a_{1}+a_{2} x_{i}\right)\right] & =M\left[y_{i}\right] \\
M\left[\left(a_{1}+a_{2} x_{i}\right) x_{i}\right] & =M\left[y_{i} x_{i}\right]
\end{aligned}
$$

ahol

$\mathrm{x}_{\mathrm{i}}$ : eljutási távolság az adott relációban

$\mathrm{y}_{\mathrm{i}}$ : eljutási idő az adott relációban.

Harmadfokú polinom alkalmazása során egy olyan

$$
f(x, \underline{a})=a_{1}+a_{2} x+a_{3} x^{2}+a_{4} x^{3}
$$

alakú függvény (8) keresendő, ahol az ismeretlen $\mathrm{a}=\left[\mathrm{a}_{1}, \mathrm{a}_{2}, \mathrm{a}_{3}, \mathrm{a}_{4}\right]$ értékek $\mathrm{a}$

$$
\begin{aligned}
M\left[\left(a_{1}+a_{2} x_{i}+a_{3} x_{i}^{2}+a_{4} x_{i}^{3}\right)\right] & =M\left[y_{i}\right] \\
M\left[\left(a_{1}+a_{2} x_{i}+a_{3} x_{i}^{2}+a_{4} x_{i}^{3}\right) x_{i}\right] & =M\left[y_{i} x_{i}\right] \\
M\left[\left(a_{1}+a_{2} x_{i}+a_{3} x_{i}^{2}+a_{4} x_{i}^{3}\right) x_{i}{ }^{2}\right] & =M\left[y_{i} x_{i}{ }^{2}\right] \\
M\left[\left(a_{1}+a_{2} x_{i}+a_{3} x_{i}{ }^{2}+a_{4} x_{i}^{3}\right) x_{i}{ }^{3}\right] & =M\left[y_{i} x_{i}{ }^{3}\right]
\end{aligned}
$$

egyenletekből (9), (10), (11), (12) álló egyenletrendszer megoldásával kaphatók meg.

Az (1), (2), (3), (4) alapján az ötödfokú polinom megadásához szükséges egyenletrendszer meghatározható, amelynek részletes kifejtésétől annak bonyolultsága miatt eltekintünk.
Az előzőekben említett páratlan kitevőjü polinomok alkalmazásának minősége - azaz az adatokra való illeszkedése - a regressziós analízissel jellemezhető, amely során egy (r) regressziós együttható képezhető a vizsgált változók között lévő kapcsolat leírására. Annál jobban illeszkedik egy polinom az adatsorra, minél jobban megközelíti az „1" értéket az „r” értéke [20].

2. táblázat: Regressziós együtthatók értékei az egyes polinomok esetében

\begin{tabular}{|c|c|c|}
\hline \multirow{2}{*}{} & \multicolumn{2}{|c|}{ Regressziós együttható $(\boldsymbol{r})$} \\
\cline { 2 - 3 } & Autóbusz & Vonat \\
\hline Lineáris & 0,93 & 0,89 \\
\hline Harmadfokú polinom & 0,94 & 0,89 \\
\hline Ötödfokú polinom & 0,94 & 0,91 \\
\hline
\end{tabular}

$\mathrm{Az}$ adatpárokra a megfelelő regressziós függvényt (5), (8) illesztve elmondható, hogy az autóbusz értékeire a harmadfokú polinom alkalmazható a lehető legkisebb hibával. Ötödfokú polinommal való közelítés, - a harmadfokúval egyező regressziós mutató-érték miatt - felesleges, mivel a számítás már túl bonyolult.

A vasút esetén a lineáris regressziós függvény illeszthető legjobban a vizsgált adatpárokra. Ugyan a 2. táblázat alapján az ötödfokú polinom adja a kedvezőbb értéket, de a 100 kilométer alatti adatsorra ez nem alkalmazható, hiszen körülbelül 30 kilométeres eljutási távolságnál 0 perc eljutási időértéket venne fel a függvény. (A későbbi vizsgálatok során a regressziós együttható részletes bemutatásától eltekintünk.)

A kapott eredményeket a 3. ábra szemlélteti.

A 3. ábra alapján megállapítható, hogy a vizsgált közlekedési módok eljutási idő és eljutási távolság viszonya három szakaszra osztható.

Az első szakaszban, Budapesttől számított, körülbelül $150 \mathrm{~km}$-es távolságon (3. ábra) belül lévő településeknél kialakulhat versenyhelyzet, amelynek több oka van:

- az autóbusz kiszolgálhat olyan településrészeket, amelyek megközelítése autópályát igénybe vevő autóbusszal kedvezőbb, mint 


\section{Közösségi közlekedés}

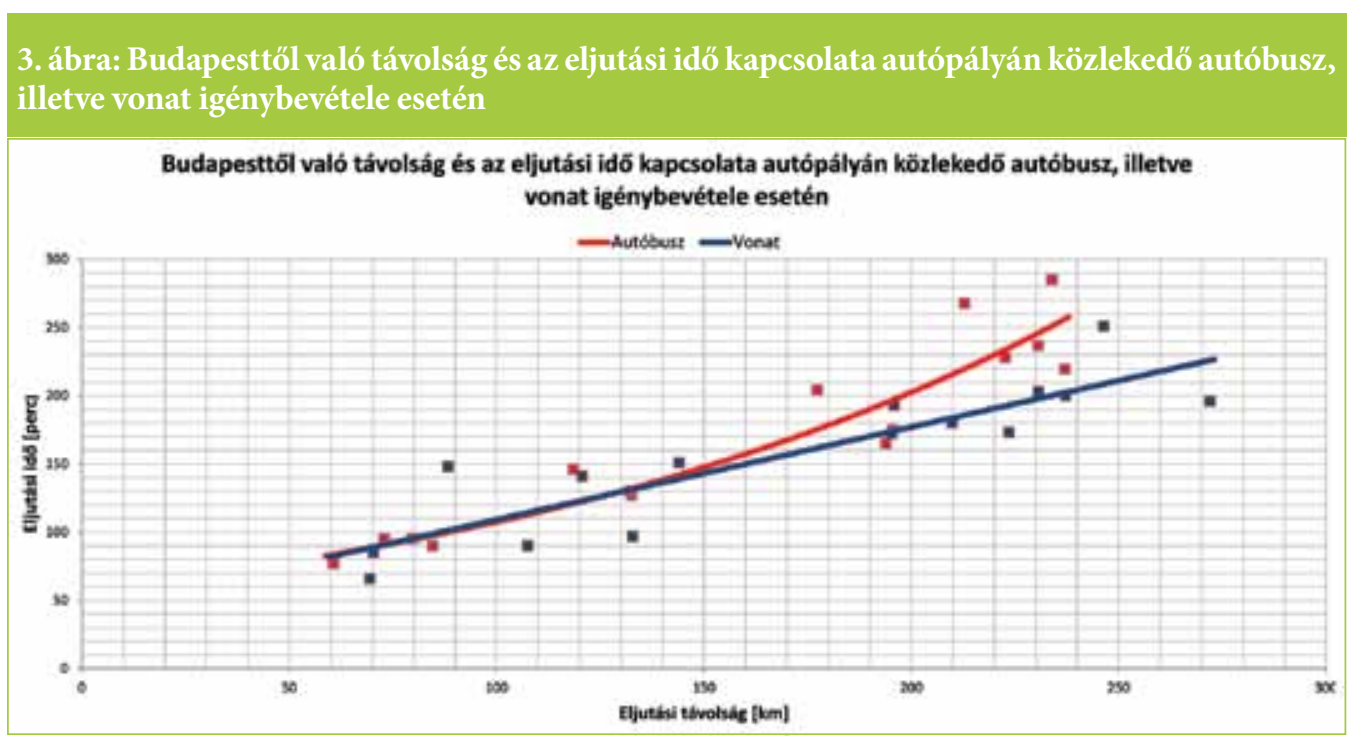

a vonattal (például Székesfehérvár Budai úti lakótelep, Kecskemét-Széchenyiváros, Hatvan-Kerekharaszt);

- ahol a vasútállomás a külvárosban, az autóbusz-állomás a belvárosban van, ott a vasútra a rá- és elhordás miatt a vasút hasonló utazási paramétereket garantál (például Dunaújváros)

- a vasútra a rá- és elhordási idők nagyok a helyi járatok és a vasút közötti menetrendi átszállási kapcsolatok hiánya miatt (a közlekedési szövetség megoldhatná ezt a problémát, például Eger),

- ezzel a vasúti fejlesztés, pályasebesség emelése nem váltja ki az optimális hatást (például Székesfehérvár);

- az autópályán közlekedő autóbuszok egy része rendelkezik Tempo100-as - azaz az autóbusz autópályán $100 \mathrm{~km} / \mathrm{h}$ maximális sebességgel közlekedhet - vizsgával és ez a szám az új jármübeszerzésekkel emelkedik,

- ezen eljutási távolságon belül nem jelentkeznek meghatározó kényelmi vagy minőségi igények/elvárások a felhasználó részéről.

- Következtetés, hogy ezen a szakaszon - az utasszám függvényében - érdemes mind a két közlekedési módot fenntartani.

A második szakaszban (4. ábra) - 150 és 180 kilométer között - minimális különbség (körülbelül 10 perc) érzékelhető az eljutási idő tekintetében a két közlekedési mód között. Eb- ben az esetben az adott viszonylatra kiterjedő forgalomszervezési vizsgálatok (forgalomszámlálás, felhasználók kikérdezése, a vonalak hálózatban betöltött szerepének vizsgálata, részletes üzemeltetési költségek, menetrendi struktúra újragondolása stb.) szükségesek, amelyek alátámasztják vagy éppen elvetik a párhuzamos közlekedésnek az indokoltságát.

A $180 \mathrm{~km}$ feletti távolságon - azaz a harmadik szakaszban - túl lévő településeken (4. ábra) az autóbusz a vasútra ráhordó szerepet tölt be. Ezen szakaszon a rá- és elhordási idők nem számottevők az utazási időhöz képest, ezért az autóbusz eljutási ideje exponenciálisan növekszik. Az autóbusznál viszont számottevő mértéket ölt a városközpontból való ki-, illetve a városközpontba való bejutás (forgalmi torlódások, forgalomirányító jelzőlámpák stb.), mivel az autóbusz-állomások többsége ott található.

Jelenleg Magyarországon számos olyan, Budapesttől számított 180 kilométer távolságon túli település van, amelyet az autóbusz a vasúttal párhuzamosan és versenyképesen - sőt, számos esetben kedvezőbb paraméterekkel szolgálhat ki.

Budapest és Zalaegerszeg között közlekedő vasúti szerelvények Bobától Zalaegerszegig minden állomáson és megállóhelyen, azaz 


\section{Közösségi iözlekedés}

körülbelül 4-5 kilométerenként megállnak, pedig a kiépítési pályasebesség $120 \mathrm{~km} / \mathrm{h}$ ! Ezzel szemben az autóbuszok nem töltik be a „falujáró” szerepet, mert Balatonszentgyörgytől az autópályán, emelt sebességgel $^{1}$ közlekednek, odáig pedig csak a föbb településeken állnak meg (pl. Keszthely, Hévíz, Sármellék).

Fontos befolyásoló tényező az állomások térbeni elhelyezkedése. Amíg az autóbusz-állomások általában a köz-

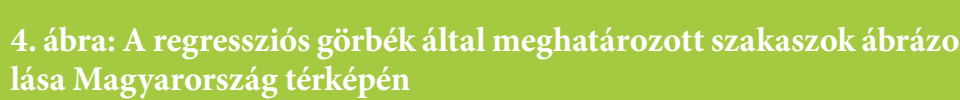
lása Magyarország térképén

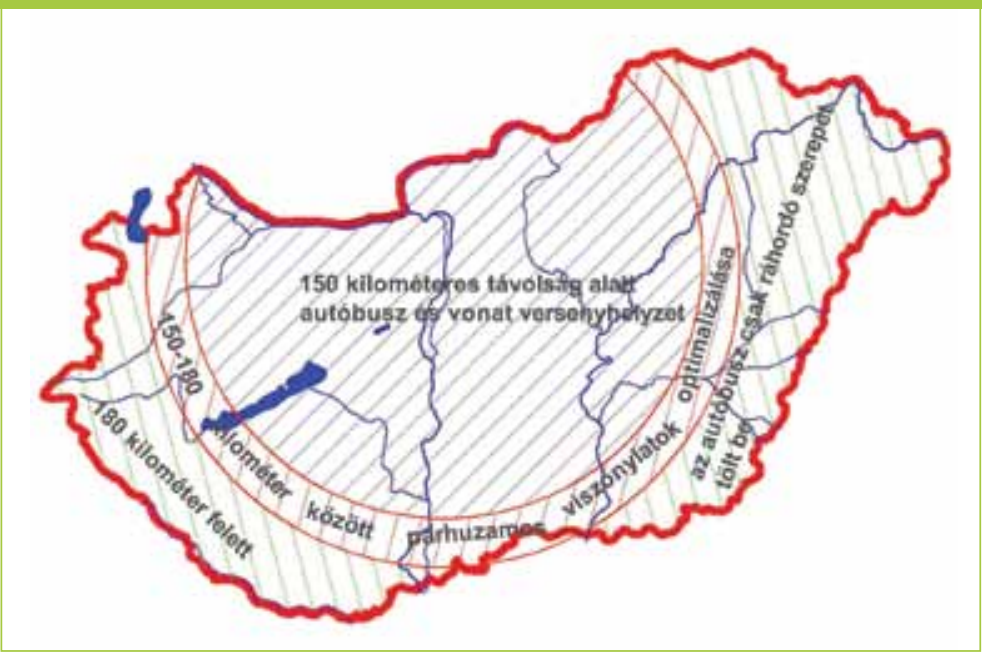
pontban találhatók (nincs szükség rá- és elhordásra), addig a vasútállomások a központtól távolabb helyezkednek el.

Megállapítható tehát, hogy a vasút 180 kilométer feletti, eljutási időben betöltött dominanciája az alábbi feltételek mellett valósulhat meg: - a megrendelők (állami vagy önkormányzati) és a különböző szolgáltatók (vasúti vagy autóbuszos) együttmüködésével olyan átszállási kapcsolatok kiépítése mind menetrendileg (pl. menetrendi pókok), mind fizikálisan (pl. intermodális csomópont), amelyek lehetővé teszik az átszállási idő minimalizálását a komfortigények kiszolgálása mellett,

- a vasúti viszonylatok megállóhelyeinek utasforgalmi felülvizsgálata a főváros és a vidéki megyeszékhelyek, a megyei jogú városok, lényegesebb szerepet betöltő városok közötti gyorsabb eljutás érdekében.

$\mathrm{Az}$ ismertetett matematikai módszer alapján lehetőség van annak kiszámítására, hogy a vizsgált viszonylatokon történő utazások paramétereiben milyen mértékü változtatást jelentene az, ha - a jelenlegieken kívül - az autópályán közlekedő autóbuszok mindegyike az autópályán emelt sebességgel, - menetrend-

ben is meghirdetve - $100 \mathrm{~km} / \mathrm{h}$-val közlekedhetne. Az így kapott adatokat - a fejezet elején ismertetett módon - a 3. táblázat tartalmazza. A tervezett Tempo 100-as járatok utazási idejének számítási módja a hatályos 1/1975. (II.5.) KPM-BM együttes rendelet a közúti közlekedés szabályairól alapján készült [6],[7],[10],[4].

A 3. táblázat és az előzőekben ismertetett regresszió-analízis - matematikai módszer felhasználásával készült 5. ábra alapján megállapítható, hogy a különböző közlekedési módok eljutási idő és eljutási távolság között fennálló viszony ugyanúgy három szakaszra bontható, mint az előzőekben.

Az első szakaszban (körülbelül 100 kilométerig) az autóbusz kedvezőbb eljutási idő értékekkel rendelkezik, ám a Budapest és ahhoz közel lévő városok között jelentkező utazási igény kielégítését az autóbusz-közlekedés önmagában nem képes ellátni, így a párhuzamosság fenntartása indokolt.

A másik két szakaszra már a fejezetben taglaltak mondhatók el annyi különbséggel, hogy az eljutási kilométer értékek tolódtak el, ugyanis a második szakasz értéke 150-180 kilométer-

${ }^{1}$ Hivatalos Autóbusz Menetrend 2015/2016. 2. kötet, Jelmagyarázat 


\section{Közösségi közlekedés}

ről 180-200 kilométerre, a harmadiké pedig 200 kilométer fölé emelkedett. Megállapítható, hogy az autópályán, a Tempo100-as minősítésű autóbuszok - teljes körü - alkalmazásával körülbelül 30 kilométerrel nőne az eljutási kilométer értéke az autóbusz javára.

A $100 \mathrm{~km} / \mathrm{h}$-val közlekedő autóbuszok szerepének elemzése a hazai közösségi közlekedésben - kiváltképp a párhuzamos közlekedésben - egy rendkívül összetett, számos paraméter elemzését magába foglaló témakör, amely az itt tár-

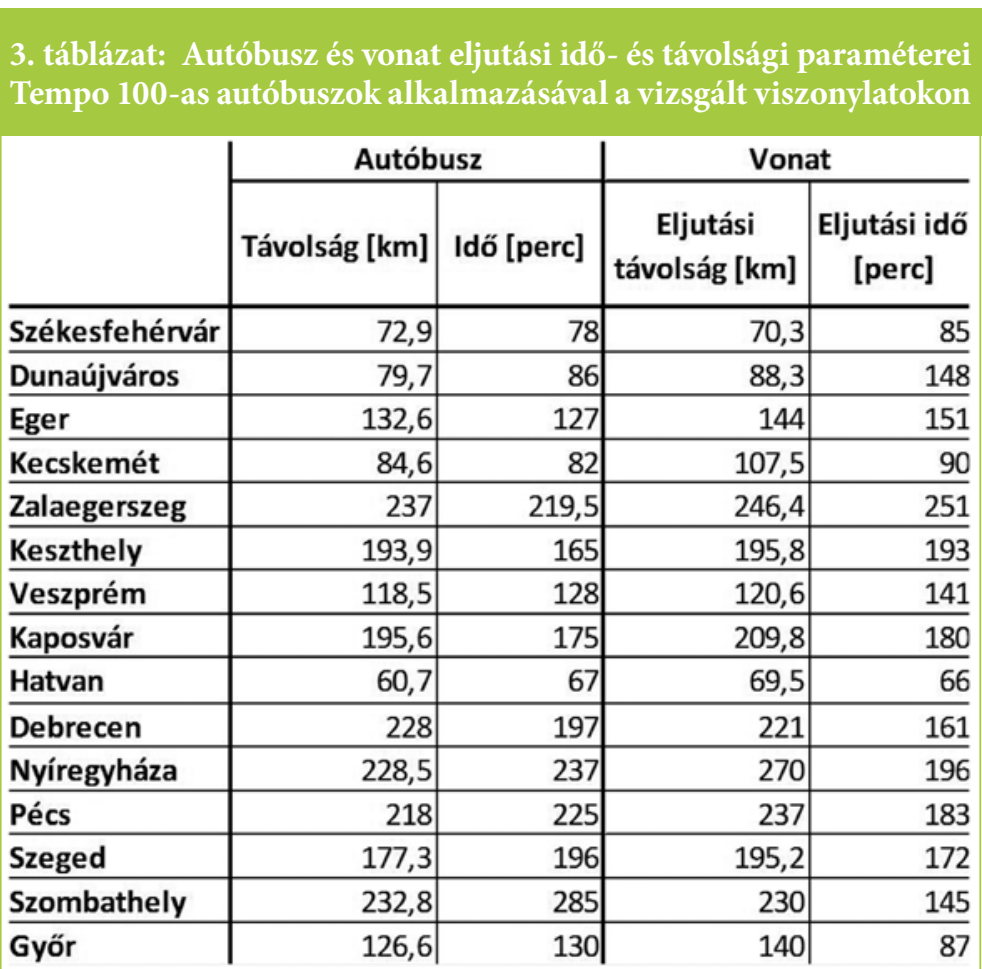

\section{5. ábra: Budapesttöl való távolság és az eljutási idő kapcsolata autó- pályán közlekedő̉ Tempo100-as minösítésü autóbusz, illetve vonat igénybevétele esetén}

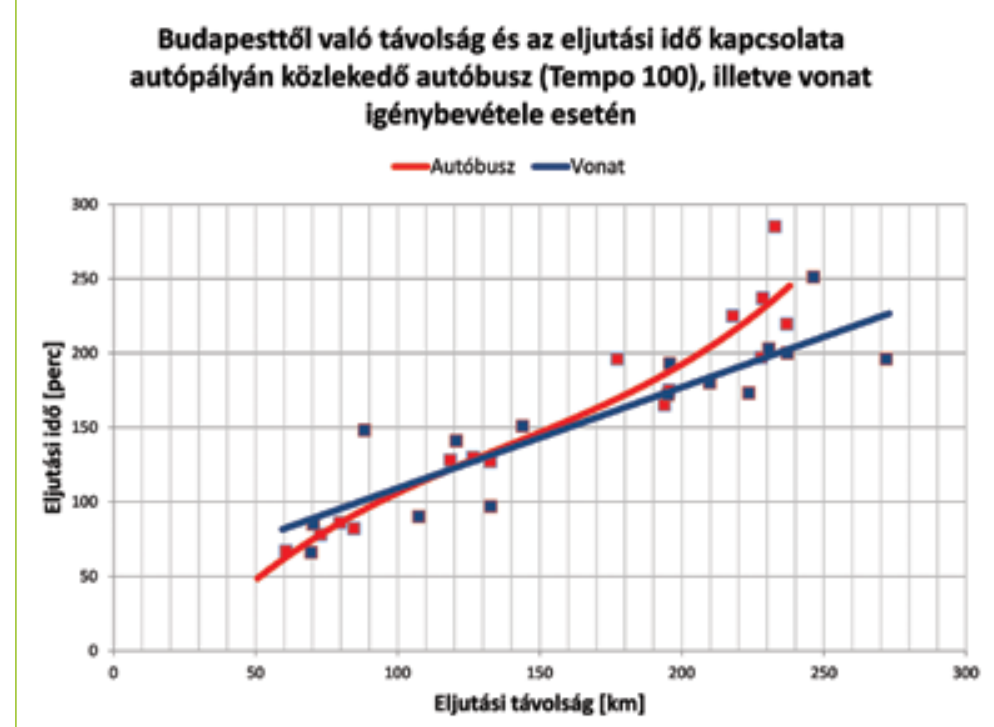

gyaltak keretein kívül esik, ezért ez a későbbi vizsgálataink részét képezi.

\subsection{Utazási költség alapján}

Az eljutási idő mellett a felhasználó eszközválasztását az utazással kapcsolatban felmerülö költségek is befolyásolják.

A vasúti és közúti szolgáltatók - ideértve a városi közlekedési vállalatokat is - a megrendelö Minisztérium és az Önkormányzat jóváhagyásával - a [22] alapján - alakítják ki díjszabásukat, amelyek az egyes szolgáltatók 


\section{Közösségi iözlekedés}

által közzétett Üzletszabályzatban találhatók meg [2],[3],[5],[9],[11],[17].

Ezek alapján, a vizsgált viszonylatokban a felhasználó az adott utazása során a közlekedési módok szerint a 4. táblázat szerinti költségeket köteles megfizetni. Az utazásért kifizetett öszszegek az alábbi díjtételekből állnak:

- kilométer-intervallum alapú, teljes áru menetjegy a helyközi közlekedésben,

- a menetrendben jelölt, emelt szintü autóbuszos szolgáltatás esetén kiegészítő menetjegy,

- pót-, illetve helyjegy megváltása nélkül igénybe nem vehető vasúti szolgáltatás esetén a pénztárban, elővételben megvásárolt pót-, illetve helyjegy,

- Budapest városi közlekedésére érvényes vonaljegy vagy átszállójegy,

- az adott vidéki település helyi közösségi közlekedési eszközén alkalmazott vonaljegy.

A felsorolt díjtételek közül az egyes esetekben csak az adott utazási relációban megváltandókat alkalmaztuk.

Felhasználói oldalról költségcsökkentő elemként értelmezhetők a jelenleg érvényben lévő közlekedési szövetségek, közlekedésszervezők által alkalmazott egyesített jegyek vagy bérletek. A vizsgált relációkat alapul véve ilyen tekintetben jeggyel nem, bérlettel (Budapestbérlet) pedig csak Budapest és Székesfehérvár - csak vasúton -, valamint Budapest és Hatvan - autóbuszon és vasúton egyaránt - elérhető.

Az utazási költségeket a 4. táblázat tartalmazza, ahol:

- $\mathrm{K}_{\mathrm{ub}}$ : az autóbusszal történő utazás esetén a regionális Közlekedési Központ által alkalmazott menetdíj,

- $\mathrm{K}_{\mathrm{bp}}$ : a Budapesten, helyi tömegközlekedésre (BKK Zrt.) felhasználható menetjegy vagy átszállójegy,

- $\mathrm{K}_{\mathrm{vb}}$ : az autóbusszal történő utazás esetén a vidéki rá- és elhordásnak a költsége (helyi autóbuszjegy stb.),

- $\mathrm{K}_{\text {öbBp-bérlettel }}$ : azokon a kijelölt autóbuszjáratokon, amelyeken a Budapest-bérlet felhasználható a bérlettel csökkentett, összesített menetdíj mértéke,

- $\mathrm{K}_{\text {öb }}$ : az autóbusszal történő utazás során felmerült költségek összege (13).

A $\mathrm{K}_{\mathrm{ob}}$ értéke a regionális Közlekedési Központ által alkalmazott menetdíj, valamint a budapesti és a vidéki rá- és elhordás összegeként értelmezhető, azaz a

$$
K_{u b}+K_{b p}+K_{v b}=K_{\tilde{o} b}
$$

egyenlettel adható meg.

4. táblázat: Utazási költségek a vasúttal, illetve autóbusszal történő utazás esetén

\begin{tabular}{|c|c|c|c|c|c|c|c|c|c|c|c|c|}
\hline & \multicolumn{5}{|c|}{ Autóbusz } & \multicolumn{5}{|c|}{ Vonat } & \multicolumn{2}{|c|}{ Vonat-autóbusz } \\
\hline & $\begin{array}{c}K_{\mathrm{ub}} \\
\text { [forint] }\end{array}$ & $\begin{array}{c}K_{b p} \\
\text { [forint] }\end{array}$ & $\begin{array}{c}K_{\mathrm{vb}} \\
\text { [forint] }\end{array}$ & $\begin{array}{c}K_{\text {¿o Bp }} \\
\text { bérlettel } \\
\text { [forint] }\end{array}$ & $\begin{array}{c}\mathrm{K}_{\mathrm{ob}} \\
\text { [forint] }\end{array}$ & $K_{u v}[$ forint $]$ & $\begin{array}{c}K_{\mathrm{bp}} \\
\text { [forint] }\end{array}$ & $\begin{array}{c}K_{v v} \\
\text { [forint] }\end{array}$ & $\begin{array}{c}K_{\text {ôv Bp bérlettel }} \\
\text { [forint] }\end{array}$ & $\begin{array}{c}K_{\ddot{b}} \\
\text { [forint] }\end{array}$ & $\begin{array}{l}\Delta \mathrm{K}_{\mathrm{o}} \\
\text { [forint] }\end{array}$ & $\begin{array}{c}\Delta \mathrm{K}_{\mathrm{b} \mathrm{Bp}} \\
\text { bérlettel } \\
\text { int }]\end{array}$ \\
\hline Székesfehérvár & 1450 & 350 & 0 & - & 1800 & 1300 & 530 & 280 & 1210 & 2110 & 310 & -240 \\
\hline Dunaújváros & 1490 & 350 & 0 & - & 1840 & 1490 & 530 & 240 & - & 2260 & 420 & - \\
\hline Eger & 2725 & 350 & 0 & - & 3075 & 2725 & 350 & 255 & - & 3330 & 255 & - \\
\hline Kecskemét & 1830 & 350 & 0 & - & 2180 & 2375 & 350 & 0 & - & 2725 & 545 & - \\
\hline Zalaegerszeg & 4305 & 350 & 0 & - & 4655 & 4305 & 530 & 0 & - & 4835 & 180 & - \\
\hline Keszthely & 3705 & 350 & 0 & - & 4055 & 3705 & 530 & 0 & - & 4235 & 180 & - \\
\hline Veszprém & 2375 & 350 & 0 & - & 2725 & 2375 & 530 & 250 & - & 3155 & 430 & - \\
\hline Kaposvár & 3705 & 350 & 0 & - & 4055 & 4315 & 530 & 0 & - & 4845 & 790 & - \\
\hline Hatvan & 1120 & 350 & 0 & 930 & 1470 & 1450 & 350 & 0 & 930 & 1800 & 330 & 0 \\
\hline Debrecen & 4305 & 350 & 400 & - & 5055 & 4605 & 350 & 400 & - & 5355 & 300 & - \\
\hline Nyíregyháza & 4305 & 350 & 0 & - & 4655 & 5140 & 350 & 0 & - & 5490 & 835 & - \\
\hline Pécs & 3690 & 350 & 0 & - & 4040 & 4605 & 530 & 400 & - & 5535 & 1495 & - \\
\hline Szombathely & 4305 & 350 & 0 & - & 4655 & 5400 & 530 & 275 & - & 6205 & 1550 & - \\
\hline Gyôr & 2725 & 350 & 0 & - & 3075 & 3025 & 530 & 0 & - & 3555 & 480 & - \\
\hline
\end{tabular}




\section{Közösségi közlekedés}

A vasút esetében az utazás költségének jelölése és számítása hasonló az autóbuszéhoz, azaz

$$
K_{u v}+K_{b p}+K_{v v}=K_{\ddot{o v}}
$$

ahol

- $\mathrm{K}_{\mathrm{uv}}$ : a vasúttal történő utazás esetén az Üzletszabályzatban meghatározott menetdíj,

- $\mathrm{K}_{\mathrm{vv}}$ : a vasúttal történő utazás során a vidéki rá- és elhordásnak a költsége (helyi autóbuszjegy stb.),

- $\mathrm{K}_{\text {övBp-bérlettel }}$ : azokon a kijelölt vonatokon, amelyeken a Budapest-bérlet felhasználható a bérlettel csökkentett, összesített menetdíj mértéke,

- $\mathrm{K}_{\text {öv }}$ : a vasúttal történő utazás során felmerült költségek összege (14).

A két közlekedési mód közötti utazási költség különbséget a $\Delta \mathrm{K}_{\mathrm{o}}(15)$ és a $\Delta \mathrm{K}_{\text {öBp-bérlettel }}(16)$, (17) mutatja, amelyek számítása a

$$
K_{\bar{o} v}-K_{\ddot{o} b}=\Delta K_{\ddot{o}}
$$

és a

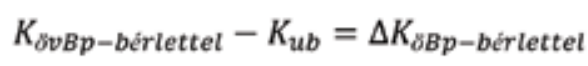

vagy a

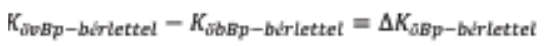

képletekkel lehetséges attól függően, hogy az adott autóbuszjáraton vagy vonaton érvényesíthető-e a Budapest-bérlettel járó kedvezmény.

A 4. táblázat alapján elmondható, hogy Budapest és a vizsgált városok tekintetében - a Székesfehérvárra vasúttal, Budapest-bérlet birtokában eset kivételével - az autóbusz igénybe vételének esetén kedvezőbb utazási költségek jelentkeznek a felhasználó oldalán, amelyek a következő okokkal magyarázhatók:

- az egyes, vonattal történő utazások esetében a kedvezőbb eljutási időt kínáló Kelenföld vasútállomás megközelítése átszállójeggyel lehetséges Budapest központjából (dunántúli utazás),

- a vasút tekintetében a vidéki városok döntő részében szükség van rá-, illetve elhordásra, amelyhez a felhasználónak helyi közösségi közlekedési menetjegyet kell váltania (például Zalaegerszeg, Eger, Dunaújváros, Veszprém),

- a vasúti szolgáltatók által alkalmazott pót-, illetve helyjegyek ára magasabb lehet az autóbusznál alkalmazott kiegészítő jegynél (például Pécs, Nyíregyháza, Szombathely),

- az adott viszonylatban az autóbuszhoz képest a vonat által megtett kilométer nagyobb, így az a díjtételeknél alkalmazott következő kilométer-intervallumba esik (például Kecskemét, Kaposvár, Nyíregyháza, Pécs).

\section{ESZKO̊ZVÁLASZTÁS ŮZEMELTE- TỎI SZEMPONTBÓL}

Az üzemeltetőnél jelentkező költségek meghatározása összetett feladat, hiszen a jármüés pályahasználati díjon felül egyéb költségek (kiszolgáló személyzet, létesítmények fenntartása, tárolás stb.) is szerepet játszanak, amelyeket - mikroszkopikus, az adott vonalra kiterjedő részletes vizsgálat nélkül - csak becsülni lehet. A [15],[16],[19] alapján becsült, jármüre vonatkoztatott, - de a pálya és egyéb költsége-

\begin{tabular}{|c|c|c|}
\hline \multicolumn{3}{|c|}{ 5. táblázat: Jármütípusonkénti üzemköltségek } \\
\hline & Jármütípus & Költség [Ft/km] \\
\hline Autóbusz & Dízel & 531 \\
\hline \multirow{3}{*}{ Vonat } & 2 csatolt FLIRT & 2750 \\
\hline & V43 & 2928 \\
\hline & $\begin{array}{c}\text { Traxx,Taurus, } \\
\text { ÖBB } 1116\end{array}$ & 2811 \\
\hline
\end{tabular}
ket is tartalmazó - kilométerenkénti költségértékeket az 5. táblázat tartalmazza.

Mivel a közúti és vasúti személyszállító járművek különböző kapacitásúak, ezért szükséges az egy férőhelyre jutó fajlagos költségek kiszámítása adott viszonylatonként. A vasútnál felmerülö értékek meghatározása a [14] alapján, Budapest és az adott település között közlekedő vonatok által nyújtott kapacitások átlagolásával történt, míg az autóbusznál az 


\section{Közösségi iözlekedés}

adott viszonylaton alapjáratként közlekedő autóbuszok kapacitását (2 vagy 3 tengelyes) vettük figyelembe, az esetlegesen mentesítő járatként (másod- vagy harmadrész) induló autóbusz(ok) kapacitásától eltekintettünk. Az 5. táblázat és az előzőekben rögzítettek alapján kiszámíthatók az eddigiekben vizsgált városokat illetően az autóbuszra és vonatra vonatkoztatott egy férőhelyre jutó fajlagos költségek a (18) alapján.

$$
\text { Fajlagos költség }=\frac{\text { utazási távolság } \cdot \text { költség }}{\text { féröhely }}
$$

azt mutatták, hogy a vasútnak kedvezőbb értéket kellene felvennie az autóbusznál, míg ez a gyakorlatban pont fordítva történik.

Ebben az esetben (7. ábra) már olyan lineáris regressziós egyenesek illenek legjobban mind az autóbusz, mind pedig a vasúti fajlagos költségekre, amelyek között minimális különbség van.

$\mathrm{Az}$ üzemeltetőnél jelentkező költségek terén tehát megállapítható, hogy Kaposvár és Zalaegerszeg tekintetében az autóbusz és a
$\mathrm{Az}$ így kapott fajlagos költségértékeket a 6 . táblázat és a 7. táblázat tartalmazza.

A 3. fejezetben már ismertetett matematikai módszer (regresszió-analízis), valamint a 6 . táblázat és a 7. táblázat alapján lehetőség van az autóbusznál és a vasútnál jelentkező fajlagos költségek közötti kapcsolat vizsgálatára.

A 6. ábra alapján kitünik, hogy a vizsgált viszonylatokat érintően az autóbusz és a vasút fajlagos költségei tekintetében lineáris függvény illeszthetö, amelyek széttartanak. Ez azt jelenti, hogy körülbelül 150 kilométeres távolság felett az autóbusznak kedvezőbb a férőhelyre vetített üzemeltetési költsége. Érdemes megvizsgálni a fajlagos költségek alakulását Kaposvár és Zalaegerszeg városok nélkül. Ezen települések neve már felmerült a 3. fejezetben is, hiszen az eljutási idő és az eljutási távolság kapcsolatának meghatározására felállított regressziós egyenesek
6. táblázat: Autóbuszra számított fajlagos költségek

\begin{tabular}{|l|c|c|c|c|c} 
& \multicolumn{5}{|c}{ Autóbusz } \\
\cline { 2 - 6 } & $\begin{array}{c}\text { Utazási } \\
\text { távolság [km] }\end{array}$ & $\begin{array}{c}\text { Autóbusz } \\
\text { tengelyeinek } \\
\text { száma }\end{array}$ & $\begin{array}{c}\text { Teljes } \\
\text { költség [Ft] }\end{array}$ & Féróhely & $\begin{array}{c}\text { Fajlagos költség } \\
\text { [Ft/féróhely] }\end{array}$ \\
\hline Székesfehérvár & 68 & 2 & 36320 & 50 & 726 \\
\hline Dunaújváros & 75 & 2 & 39931 & 50 & 799 \\
\hline Eger & 128,3 & 2 & 68127 & 50 & 1363 \\
\hline Debrecen & 217,4 & 2 & 115541 & 50 & 2311 \\
\hline Nyíregyháza & 226,3 & 2 & 120271 & 50 & 2405 \\
\hline Pécs & 208,3 & 2 & 110705 & 50 & 2214 \\
\hline Szeged & 172,8 & 2 & 91838 & 50 & 1837 \\
\hline Kecskemét & 80,1 & 2 & 42533 & 50 & 851 \\
\hline Zalaegerszeg & 232,5 & 3 & 123458 & 65 & 1899 \\
\hline Keszthely & 189,4 & 3 & 100571 & 65 & 1547 \\
\hline Kaposvár & 191,1 & 2 & 101474 & 50 & 2029 \\
\hline Szombathely & 229,4 & 2 & 121919 & 50 & 2438 \\
\hline Györ & 127,6 & 2 & 67815 & 50 & 1356 \\
\hline Veszprém & 114 & 2 & 60534 & 50 & 1211 \\
\hline Hatvan & 56,4 & 2 & 29948 & 50 & 599 \\
\hline
\end{tabular}

7. táblázat: Vasútra számított fajlagos költségek

\begin{tabular}{|c|c|c|c|c|c|}
\hline & \multicolumn{5}{|c|}{ Vonat } \\
\hline & \begin{tabular}{|c|} 
Utazási \\
távolság [km] \\
\end{tabular} & $\begin{array}{c}\text { Mozdony } \\
\text { "kategória" }\end{array}$ & $\begin{array}{c}\text { Teljes } \\
\text { költség [Ft] }\end{array}$ & Férőhely & \begin{tabular}{|c}
$\begin{array}{c}\text { Fajlagos költség } \\
\text { [Ft/féröhely] }\end{array}$ \\
\end{tabular} \\
\hline \multirow{2}{*}{ Székesfehérvár } & \multirow{2}{*}{63} & 2 csatolt FURT & 173242 & 400 & \multirow{2}{*}{464} \\
\hline & & V43 & 184471 & 321 & \\
\hline Dunaújváros & 80 & 2 csatolt FURT & 219990 & 373 & 590 \\
\hline Eger & 140 & $\mathrm{~V} 43$ & 409935 & 328 & 1251 \\
\hline Debrecen & 221 & V43 & 647112 & 307 & 2108 \\
\hline Nyiregyháza & 270 & V43 & 790589 & 292 & 2707 \\
\hline Pécs & 224 & V43 & 655896 & 238 & 2756 \\
\hline Szeged & 191 & V43 & 559269 & 438 & 1276 \\
\hline Kecskemét & 106 & V43 & 310380 & 438 & 709 \\
\hline Zalaegerszeg & 239 & V43 & 699818 & 194 & 3605 \\
\hline Keszthely & 190 & V43 & 556341 & 613 & 908 \\
\hline Kaposvár & 204 & V43 & 597334 & 73 & 8201 \\
\hline Szombathely & 230 & Traxx, Taurus & 646530 & 275 & 2352 \\
\hline Györ & 127 & Traxx, Taurus & 356997 & 302 & 1182 \\
\hline Veszprém & 112 & V43 & 327948 & 317 & 1035 \\
\hline Hatvan & 67 & V43 & 196183 & 372 & 528 \\
\hline
\end{tabular}




\section{Közösségi közlekedés}

6. ábra: Férőhelyre vonatkoztatott fajlagos költségek alakulása a távolság függvényében

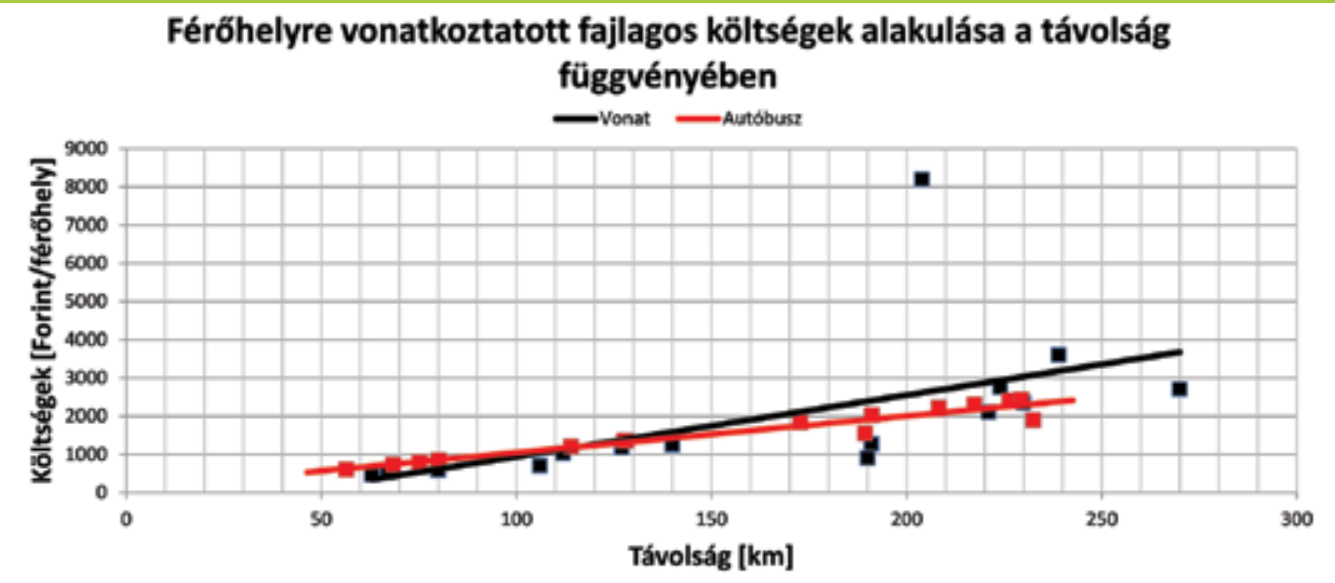

7- ábra: Férőhelyre vonatkoztatott fajlagos költségek alakulása a távolság függvényében (Kaposvár és Zalaegerszeg nélkuil)

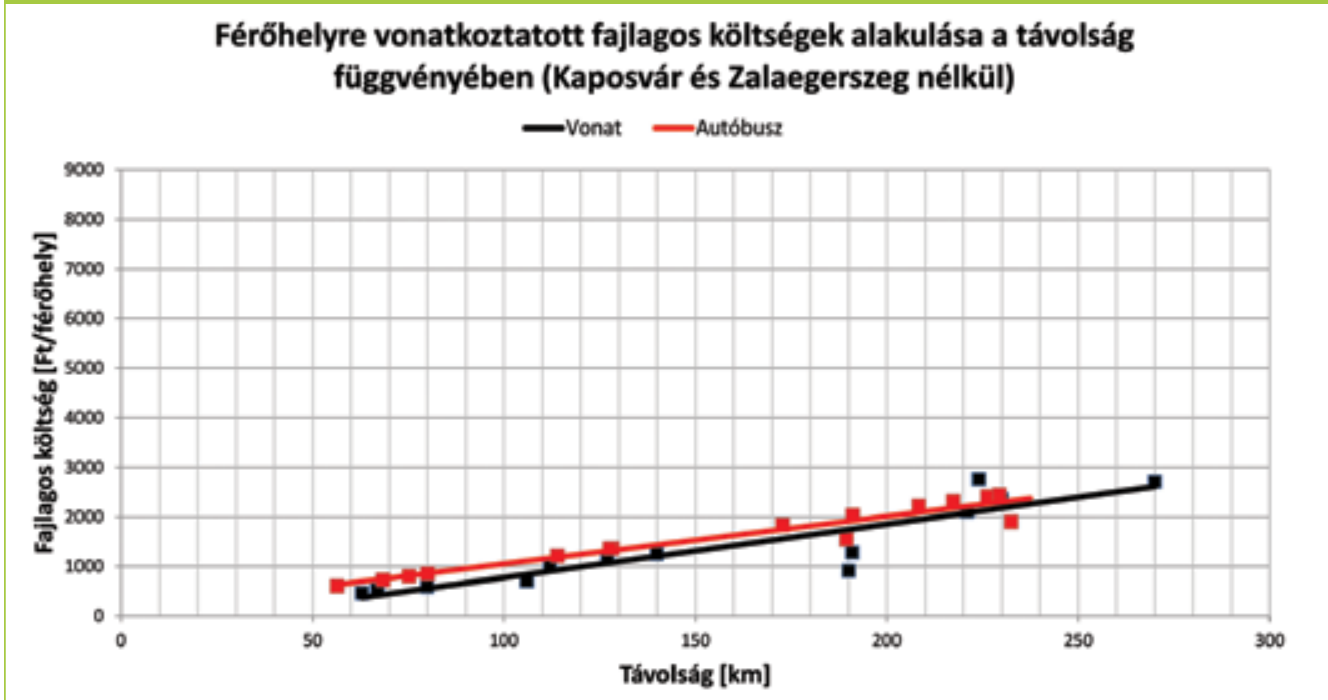

vasút párhuzamos közlekedésének optimalizálásával az üzemköltségek csökkenthetök - a 3. fejezetben ismertetett forgalomszervezési beavatkozásokon túl - a vonatok kapacitásának növelésével a felmerülő közlekedési igények függvényében.A költségek finanszírozása jelenleg a regionális Közlekedési Központok és a MÁV-Start Zrt. eladott jegyein/ bérletein felül állami - tulajdonosi - kompenzációval történik. Ezért elengedhetetle- nül fontos az állami kompenzációt illetően is a párhuzamos járatok optimalizálása, hiszen ezek „párhuzamos” anyagi kiegészítést is vonhatnak maguk után, ami többletköltségekkel járhat.

\section{KONKLÚZIÓ}

Magyarországon napjainkban a közösségi közlekedésben problémát jelent a párhu- 


\section{Közösségi iözlekedés}

zamos közlekedés - azaz két város közötti autóbuszos és vasúti kínálat - kérdése. A fenntartható közlekedés és a hazai közlekedéspolitika megköveteli, hogy a különböző közlekedési módok egymás kiegészítői legyenek. Ehhez szükséges a párhuzamosan futó vonalak vizsgálata, illetve forgalommegosztásának optimalizálása.

A téma összetettségéből adódóan jelen vizsgálat csak olyan Budapeströl induló, megyeszékhelyek (vagy 20 ezer fönél nagyobb lakos számú város) úti célú viszonylatokra terjed ki, ahol a használt pálya minőségi paraméterei bizonyos kritériumnak (vasút esetében minimum $100 \mathrm{~km} / \mathrm{h}$-s kiépítési sebesség, az autóbusz útvonala pedig részben vagy teljes egészében autópályával fedett) megfelelnek. A pálya minősége mellett a hálózaton töltött idő (eljutási idő) minimalizálása is a vizsgálat fontos kritériumfeltételeként jelenik meg, az üzemeltetőnél és a felhasználónál jelentkező költségekkel egyetemben.

A vizsgálat tárgya $15 \mathrm{db}$ viszonylatra (Zalaegerszeg, Keszthely, Győr, Szombathely, Kecskemét, Hatvan, Debrecen, Nyíregyháza, Eger, Szeged, Pécs, Kaposvár, Székesfehérvár, Dunaújváros, Veszprém) terjed ki, amelyeket $\mathrm{Bu}$ dapest városközpontjától a vidéki megyeszékhelyig vagy 20 ezer főnél nagyobb lakosszámú vidéki város városközpontjáig tartó utazási láncokkal elemeztünk.

A közösségi közlekedési módonként kapott eljutási idő és eljutási távolság adatok, valamint a regressziós-analízis matematikai módszer segítségével, a kapott egyenesek, illetve görbék alapján, a távolság függvényében a párhuzamosság kérdése három szakaszra osztható:

- a Budapesttől számított 150 kilométerig az autóbusz és a vonat között az eljutási időben eltérés nem - vagy csak nagyon csekély mértékben - tapasztalható, ezért ezen relációban megfontolandó mindkét közlekedési mód fenntartása,

- a Budapesttől számított 150 - 180 kilométer között a vasút felel meg jobban a kritérium- feltételeknek, de az eltérés kicsi, maximum 10 perc,

- a Budapesttől számított 180 kilométer felett pedig egyértelmüen a vasút bizonyul kedvezőbbnek az eljutási idő tekintetében.

A probléma aktualitását mutatja, hogy - a vizsgálati eredményekkel ellentétben - néhány esetben (például Kaposvár, Zalaegerszeg) jelenleg 180 kilométeres távolság felett is az autóbusz dominál a kínálati paraméterek (járatsűrüség, eljutási idő, üzemidő stb.) tekintetében. Ennek orvoslása egyrészről forgalomszervezési beavatkozással (például menetrendi struktúra újragondolása), másrészről pedig a helyi közösségi közlekedési szolgáltatóval való együttmüködéssel (rá- és elhordás) lehetséges.

Az elöbbiekben említett megoldások a felhasználónál jelentkező költségek minimalizálására, mint kritériumfeltételre is alkalmazhatók, hiszen a közösségi közlekedési módok közötti árkülönbséget a helyi járati menetjegyárak és a pót-, illetve helyjegyárak befolyásolják. Mivel a vasútállomások többségében a város szélén helyezkednek el, ezért az utasok városközpontba történő utazásai során helyi járatokat kénytelenek igénybe venni, ami többletköltséget okoz.

A vizsgált viszonylatokban a jelenleg közlekedő vasúti és autóbuszos jármủvek paramétereinek elemzésével, valamint a már említett matematikai módszer segítségével lehet meghatározni az üzemeltetőnél jelentkező költségeket, illetve azok közlekedési módok közötti viszonyát. Ebből kiderül, hogy a férőhelyre vetített fajlagos költségek - a kapott görbék jellegéből adódóan - körülbelül 150 kilométer felett magasabb értéket vesznek fel a vasútnál, mint az autóbusznál. A kiugró értékkel rendelkező viszonylatok esetében (például Budapest -Zalaegerszeg, valamint Budapest - Kaposvár) a forgalomszervezési eljárások optimalizálásával ezek az értékek szabályozhatók. Az autóbuszos és a vasúti közlekedés egyidejü fenntartása esetén az üzemeltetőnél jelentkező fajlagos költségek kiegyenlítődnek. 


\section{FELHASZNÁLT IRODALOM}

[1] A BKK Zrt. által megrendelt közösségi közlekedési járművek menetrendjei. Letöltés dátuma: 2016. június 10., forrás: http://www.bkk.hu/menetrendek

[2] A Budapesti Közlekedési Központ Zrt. Üzletszabályzata (hatályos: 2014. október 07. napjától). Letöltés dátuma: 2016.. június 10., forrás: http://www.bkk.hu/apps/docs/ kozerdeku/20141007.pdf

[3] AKMKKKözépkelet-magyarországi Közlekedési Központ Zrt. Üzletszabályzata 2.2. számú melléklet. (2015. január 1.). Letöltés dátuma: 2016. augusztus 19., forrás: http:// $\mathrm{kmkk}$.hu/index.php?option $=$ com_ content\&view $=$ article\&id $=13$

[4] A koncessziós M6 autópálya részletes térképe. Letöltés dátuma: 2016 .. június 10., forrás: http://www.m6duna.hu/m6-szolgaltatasok/m6trkpek/21.htm

[5] Az ÉNYKK Északnyugat-magyarországi Közlekedési Központ Zrt. Üzletszabályzata 4. sz. módosítás. (2016. január 20.). Letöltés dátuma: 2016.. augusztus 19., forrás: http:// www.enykk.hu/cikk/kozzetetel. html

[6] Az M3 autópálya vonalvezetése. Letöltés dátuma: 2016.. június 10., forrás: http://motorways-exitlists.com/ europe/h/m3.htm\#m3_m30

[7] Az M7 autópálya vonalvezetése. Letöltés dátuma: június. 10., forrás: http://motorways-exitlists.com/ europe/h/m7.htm

[8] Hivatalos Autóbusz Menetrend 2-20. kötete a 2015/2016. évre.

[9] Kivonatos tájékoztató az autóbuszszal végzett helyközi menetrend szerinti személyszállításról szóló Közszolgáltatási Szerződés viteldíjairól. Hivatalos Autóbusz Menetrend 5. számú kötet 2015/2016 (old.: 30-31). Miskolc: ÉMKK Zrt.

[10] M5 autópálya csomópontjai és pihenői. Letöltés dátuma: 2016. június 10.,
[14] Vonatösszeállítás. Letöltés dátuma: 2016.. június 10., forrás: http:// vonatosszeallitas.hu

[15] Traxx-tapasztalatok: takarékosak a mozdonyok. http://iho.hu/hir/ traxx-tapasztalatok-takarekosak-amozdonyok-120306\#

[16] Ezerarcú Magyarország. Letöltés időpontja: 2016. október 20. http:// www.volanbusz.hu/files/public/ rpdf/Kulonjaratiajanlatcsomag_2_ 1024x768px.pdf

[17] Pót- és helyjegy árak. Letöltés dátuma: 2016.október 20. https://www. mavcsoport.hu/mav-start/belfoldiutazas/arak-es-kedvezmenyek/potes-helyjegyarak

[18] dr. Péter Tamás: Matematikai Módszerek I. PhD egyetemi jegyzet. Letöltés ideje: 2016. szeptember 10.

[19] Hálózati Ügyfélszolgálat. Letöltés dátuma: 2016. október 20. https://www2.vpe.hu/hu/halozatiuzletszabalyzat-husz

[20] Két mennyiség kapcsolatának vizsgálata, korreláció és lineáris regreszszió. Letöltés dátuma: 2016. augusztus 8. http://rs1.szif.hu/ szorenyi/ elm/bioselm7.htm

[21] Lakatos András: A budapesti villamosközlekedés versenyképességének fejlesztése

[22] 1990. évi LXXXVII. törvény az árak megállapításáról (letöltés dátuma: 2016. augusztus 5.) forrás: http:// net.jogtar.hu/jr/gen/hjegy_doc. cgi?docid $=99000087 . \mathrm{TV}$ 


\section{Közösségi iözlekedés}

Questions about the parallelism of railway passenger and coach passenger transport in Hungary, from the point of view of travel parameters

A recurring question in Hungary's transport is the issue of the parallelism of longdistance bus and rail passenger transport, since sustainable and efficient transport as well as transport policy in Hungary require that the sub-sectors are complementary to each other. There are currently several parallel bus and rail public transport services between a number of major cities and the capital, Budapest, which results in a competitive situation between the two sub-sectors, thus their roles are not complementary to each other. In order to address this problem, it is necessary that the existing parallel public transport opportunities are optimized.

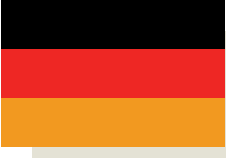

\section{Fragen zur Parallelität der Personenbeförderung mittels Eisenbahn- und}

Fernbusverkehr in Ungarn, unter dem Gesichtspunkt der Reiseparameter

Eine wiederkehrende Frage im ungarischen Verkehr ist die Frage der Parallelität des Fernbus- und Schienenpersonenverkehrs, da ein nachhaltiger und effizienter Verkehr sowie die Verkehrspolitik in Ungarn die Komplementarität der Teilsektoren erfordern. Es gibt derzeit mehrere parallele Bus- und Schienenverkehrsdienste zwischen einer Reihe von Großstädten und der Hauptstadt, Budapest, die zu einer Wettbewerbssituation zwischen den beiden Teilsektoren führt, so dass ihre Rollen nicht komplementär zueinander sind. Um dieses Problem zu lösen, ist es notwendig, dass die bestehenden parallelen öffentlichen Verkehrsmöglichkeiten optimiert werden.

\section{ÚJ KONFERENCIA! \\ I. Magyar Közlekedési Konferencia}

\section{2. Útügyi Napok és 8. Nemzeti Közlekedési Napok}

Dr. Fónagy János miniszterhelyettes úr támogatásával a közutas szakterületen nagy hagyományokkal rendelkező Útügyi Napok és az összközlekedési szakmai fórumként többször megrendezésre került Nemzeti Közlekedési Napok szellemiségének továbbéltetőjeként kerül megrendezésre ez a konferencia, a Közlekedéstudományi

Egyesület szervezésében.

Helyszín: Eger

Idôpont: 2017. október 18-20.

További aktuális információ a KTE honlapján www.ktenet.hu 